\title{
Ginger extract as green biocide to control microbial corrosion of mild steel
}

\author{
Jayaraman Narenkumar ${ }^{1}$ Punniyakotti Parthipan ${ }^{1} \cdot$ Ayyakkannu Usha Raja Nanthini ${ }^{2}$. \\ Giovanni Benelli $^{3} \cdot$ Kadarkarai Murugan $^{4,5} \cdot$ Aruliah Rajasekar $^{1}$
}

Received: 10 December 2016/Accepted: 14 February 2017/Published online: 8 June 2017

(c) Springer-Verlag Berlin Heidelberg 2017

\begin{abstract}
In latest years, various techniques and chemicals have been used for the control of microbial influenced corrosion (MIC) of metals. The application of botanicalbased biocides is one of the effective and practical techniques in the fight against MIC. In the present study, the role of aqueous extract of ginger (Zingiber officinale) (GIE) as green biocide to control MIC of mild steel 1010 (MS) in a cooling water system was investigated. Biocorrosion behavior of Bacillus thuringiensis EN2 on MS and its control by GIE was analyzed by electrochemical measurements. Polarization, electrochemical studies (ES), weight loss measurements (WL), and surface analysis (XRD, X-ray diffraction spectroscopy, and FTIR, Fourier transform infra-red spectroscopy) were performed under various incubation periods up to 4 weeks. We observed that EN2 forms a thick biofilm on the MS metal surface at the end of the incubation period and the WL significantly increased to $993 \mathrm{mg}$ at fourth week when compared to the initial immersion period $(194 \pm 2 \mathrm{mg})$. In contrast, with addition of GIE, WL was reduced about $41 \pm 2 \mathrm{mg}$ over
\end{abstract}

Aruliah Rajasekar

rajasekargood@gmail.com; rajasekar.aruliah@gmail.com

1 Environmental Molecular Microbiology Research Laboratory, Department of Biotechnology, Thiruvalluvar

University, Serkkadu, Vellore 632115, Tamilnadu, India

2 Department of Biotechnology, Mother Teresa Women's University, Kodaikanal 624101, Tamilnadu, India

3 Department of Agriculture, Food and Environment, University of Pisa, viadelBorghetto 80, 56124 Pisa, Italy

4 Department of Zoology, Bharathiar University, Coimbatore 641046, India

5 Thiruvalluvar University, Serkkadu, Vellore 632115, Tamil Nadu, India biotic system (993 $\pm 2 \mathrm{mg}$ ). GC-MS analysis confirmed the adsorption of active component of GIE ( $\beta$-turmerone) on the metal surface as a protective layer to prevent the biofilm formation and thus leads to reduction of corrosion. The optimum $20 \mathrm{ppm}$ of GIE was found to be effective corrosion inhibition efficiency which was about $80 \%$. From the results of WL, ES, XRD, FTIR, and GC-MS, GIE was identified as biocide and thus inhibits the bacterial growth on MS metal surface and it leads to control MIC. XRD showed that the GIE with EN2 resulted in less formation of corrosion products over biotic and abiotic systems. Overall, this research first shed light on the antibacterial activity of GIE inhibiting biofilm formation, thus reducing the corrosion of MS in cooling water systems.

Keywords Ginger extract · Microbiological influenced corrosion · GC-MS · Mild steel

\section{Introduction}

Cooling towers are commonly used for heat transfer from circulating water to the environment. A major problem in cooling tower water system is material corrosion due to the presence of water and bacterial biofilms formation (Aquaprox 2009). A biofilm is a microbial community of cells embedded in a thick mucilaginous matrix of extracellular polymeric substances (EPS) (Lewis 2001; Rajasekar and Ting 2011). EPS are important metabolites for biofilm formation on metallic and non-metallic surfaces (Liu et al. 2007). Microbial influenced corrosion (MIC) in cooling tower water system is favored during certain environmental conditions leading to biofilm formation on metal/non-metal surfaces, such as high humidity and high doses of chloride (both from organic and inorganic 
molecules) (Swaroop et al. 2016). In such circumstances, aerobic and anaerobic bacterial biofilm growth was observed. These microbial biofilms are responsible for the corrosion of various cooling tower materials (Lutey 2001).

The mild steel is an important metal used in construction industry, due to its cost-effectiveness. However, it has low corrosion resistance in aqueous and non-aqueous environments, if compared to other metallic materials (El-Shamy et al. 2009). Hence, recent research focused on controlling the corrosion of mild steel using corrosion inhibitors biocides (Amin and Ibrahim 2011).

Essentially, the prevention of MIC would mean destroying the microbial community or preventing biofilm formation and development on metal/non-metal surfaces (Guiamet and Gomez de Saravia 2005). Various techniques have been used to control MIC, including mechanical, electrochemical, chemical, and biological ones (Javaherdashti 2008; Little and Lee 2007). Among them, chemical and biological components are the most effective and appropriate method to control MIC in different environmental conditions such as $\mathrm{pH}$, chemical, and temperature (Guiamet and Gomez de Saravia 2005).

Commonly employed corrosion inhibitors are based on organic compounds that react on metal surface thus decreasing its corrosion (Banerjee and Malhotra 1992; ElSayed 1997). A biocide can change local environmental conditions in the corrosion process inhibiting biofilm formation. In these cases, the use of green biocides can overcome the concerns associated with use of MIC organic inhibitors. Green biocides are non-toxic, abundant, lowcost, and eco-friendly (Radojcic et al. 2008). Many plant parts have been studied for its biocide activities, such as leaves, root, and shoot (Table 1) (Ansari and Quraishi 2015). Tested species included certain spices and condiments (clove, horse radish, tamarind, cinnamon, onion, and garlic) as corrosion inhibitors and biocides in acidic conditions (Krishna and Banerjee 1999; Malhotra and Singh
2005; Bhola et al. 2013). These biocide are fairly easy to handle, eco-friendly, and usually compatible with water treatment plants (Downward et al. 1997).

Ginger has widely been used as medicine for past thousands of years. Some reports are proved that the ginger acts as antimicrobial, anti-tumorigenic, anti-apoptic, antiinflammatory, and antibiotic activity (O'Hara et al. 1998; Sebiomo et al. 2011; Betoni et al. 2006; Park et al. 2008). Recently, Kim and Park (2013) reported that ginger extract has antibacterial activity and inhibits the growth of Pseudomonas aeruginosa biofilm on metal surfaces.

Hence, in the present investigation, the extract of ginger (GIE) was employed as green biocide to control biofilm formation and MS corrosion. Biocorrosion inhibition assays were carried out evaluating weight loss, electrochemical measurements (polarization and impedance) (ES), and surface chemical analysis (GC-MS, FTIR, and XRD). The surface film on MS surface was investigated by FTIR and XRD analyses. Finally, we characterized the effect of GIE on biofilm formation using a static biofilm assay, EPS, and planktonic characterization.

\section{Materials and methods}

\section{Bacteria}

Bacillus thuringiensis EN2 strain was isolated from biofilm samples on metal surface and identified by $16 \mathrm{~S}$ rDNA analysis, as described earlier (Narenkumar et al. 2016). This strain was recovered from glycerol stock and subcultured in nutrient agar plates (Himedia, Mumbai, India) and incubated at $37^{\circ} \mathrm{C}$ for $24 \mathrm{~h}$, and further subcultured by single colony inoculation method using LB broth $(\mathrm{pH}$ 7.0) and incubated in an orbital shaker $(150 \mathrm{rpm})$ for $24 \mathrm{~h}$ at $37^{\circ} \mathrm{C}$. This EN2 bacterial culture was used for further studies. The nucleoside sequence of

Table 1 Plant-based green inhibitors for control of corrosion of mild steel in various environmental conditions

\begin{tabular}{llrll}
\hline S. no & Plant source & Concentration $(\mathrm{ppm})$ & Corrosion inhibitor efficiency (\%) & References \\
\hline 1 & Azadirachta indica leaves extract & 20 & 50 & Shaily et al. (2014) \\
2 & Watermelon rind extract & 1000 & 54.33 & Odewunmi et al. (2015) \\
3 & Nicotiana tabacum leaves extract & 2500 & 80.3 & Bhawsar et al. (2015) \\
4 & Chromolaena odorata extracts & 100 & 90 & Aribo et al. (2016) \\
5 & Dryopteris cochleata leaf extracts & 400 & 54.9 & Nathiya and Raj (2016) \\
6 & Syzygium cumini seed & 50 & 71.42 & Singh and Quraishi (2013) \\
7 & Calotropis procera & 16 & 87.8 & Raja and Sethuraman (2009) \\
8 & Black pepper extract & 20 & 87.11 & Raja and Sethuraman (2008) \\
9 & Caulerpin & 10 & 76 & Kamal and Sethuraman (2012) \\
10 & Rauvolfia serpentine & 100 & 59.88 & Raja and Sethuraman (2010) \\
11 & Kappaphycus alvarezii & 41.91 & Kamal and Sethuraman (2013) \\
\hline
\end{tabular}


EN2 was deposited in NCBI under the accession number of KR183873.

\section{Preparation of aqueous ginger extract}

Ginger tubers (Zingiber officinale) were obtained from a local market in Tamil Nadu, India. Debris on the surface of tubers was removed manually, and then, they were cut into fine pieces. Following that, they were extracted using hydrodistillation method (Natta et al. 2008). Briefly, $2 \mathrm{~kg}$ of ginger pieces were added into $5 \mathrm{~L}$ distilled water and the mixture was then heated into vertical hydrodistillation unit at $100{ }^{\circ} \mathrm{C}$ for $24 \mathrm{~h}$. The ginger extract was separated through vapor and extract was stored for further investigations. The main active phytochemical components of the GIE were found to be gingerol, $\beta$ - turmerone, $\alpha$ - turmerone, curlone, and shogal.

\section{Minimal inhibition concentration of ginger extract}

The minimal inhibition concentration of GIE with EN2 was experimentally determined by the conventional agar diffusion assay, as described by Lalpuria et al. (2012). Different concentrations of GIE (i.e., 10, 15, 20, 25, and $30 \mathrm{ppm}$ ) were used for this assay. The plates were examined and the zone of inhibition was measured, and the minimal inhibition concentration was calculated.

\section{Growth inhibition test}

Overnight, culture of EN2 in nutrient broth (NB) medium was diluted 1:100 ratio with fresh medium in with and without ginger extracts $(20 \mathrm{ppm})$ and incubated for $14 \mathrm{~h}$ at $37{ }^{\circ} \mathrm{C}$. Finally OD was measured for trace bacterial growth (Greenberger et al. 1979).

\section{Static biofilm formation assay}

Biofilm growth and assay was carried out as described by Narenkumar et al. (2016). Overnight, the culture of EN2 in NB medium were diluted in 1:20 ratio with fresh NB medium with appropriated concentration of $\operatorname{GIE}(10,20$, and $30 \mathrm{ppm}$ ), and then, $100 \mu \mathrm{L}$ cultures were transferred into 96-well polystyrene microtiter plate and incubated at $37{ }^{\circ} \mathrm{C}$ for $24 \mathrm{~h}$. The suspended culture was discarded and 96-well plate was washed with phosphate-buffered saline (137 mM NaCl, $2.7 \mathrm{mM} \mathrm{KCl,} 10 \mathrm{mM} \mathrm{Na}$ HPO, $2 \mathrm{mM}$ $\mathrm{KH}$ PO, pH 7.2), and $120 \mu \mathrm{L}$ of crystal violet was added and incubated at room temperature for $20 \mathrm{~min}$. Finally, $125 \mu \mathrm{L}$ of acetic acid was added and incubated for $15 \mathrm{~min}$ at $37^{\circ} \mathrm{C}$. The product formed was measured by UV-Visible spectrophotometer at $600 \mathrm{~nm}$ (O'Tool et al. 1999).

\section{Extracellular polymeric substance analysis}

Extracellular polymeric substance (EPS) extraction of EN2 was adopted from Padmavathi et al. (2015). EPS extraction was determined with and without GIE at a concentration of 20 ppm. Extracted EPS was subjected to protein, carbohydrate, and lipids analysis by Lowry's and phenol/sulphuric acid method, respectively (Dubois et al. 1956).

\section{Swarming motility assay}

Swarming motility was assay was adopted from a previous study (Narenkumar et al. 2016). Overnight cultures of EN2 with and without ginger extract were spotted onto nutrient agar plates and incubated for $16-24 \mathrm{~h}$ at $37{ }^{\circ} \mathrm{C}$. Migration was evaluated by measuring the average length of produced dendrites.

\section{Colony morphology assay}

Overnight culture of EN2 in an NB medium was spotted into Congo red plates contain $10 \mathrm{~g} / \mathrm{L}$ tryptone, $40 \mu \mathrm{g} / \mathrm{mL}$ Congo red, $20 \mu \mathrm{g} / \mathrm{mL}$ Coomassie brilliant blue, and $1.5 \%$ agar, and incubated at room temperature for 3 days.

\section{Biofilm detachment assay}

The biofilm detachment assay was carried out into the 96-well plate method. Overnight culture of EN2 in NB medium was diluted with fresh medium (1:20) and with/ without ginger extract. The diluted culture were stored into 96-well microtiter plate and incubated at $37{ }^{\circ} \mathrm{C}$ for $24 \mathrm{~h}$. Then, $3 \mu \mathrm{L}$ of sodium dodecyl sulfate (SDS) $10 \%$ was added into each well and incubated for $30 \mathrm{~min}$. After incubation period, suspended cell was measure OD at $595 \mathrm{~nm}$ and then suspended was discarded, and plate was washed with phosphate-buffered saline solution. $120 \mu \mathrm{L}$ of crystal violet was added and incubated at room temperature for $20 \mathrm{~min}$. Finally, $125 \mu \mathrm{L}$ of acetic acid was added and incubated for $15 \mathrm{~min}$ at $37^{\circ} \mathrm{C}$. The product formed was measured by UV-Visible spectrophotometry at $600 \mathrm{~nm}$ (Kim and Park 2013).

\section{Metal preparation}

For biocorrosion study, the coupons of mild steel 1010 grade were used with the following composition: $0.03 \% \mathrm{C}$, $0.026 \% \mathrm{~S}, 0.01 \% \mathrm{P}, 0.002 \% \mathrm{Si}, 0.04 \% \mathrm{Ni}, 0.002 \% \mathrm{Mo}$, $0.16 \% \mathrm{Mn}, 0.093 \% \mathrm{Cu}$, and $99.64 \% \mathrm{Fe}$. The MS 1010 coupons with different size of 2.5 and $1 \mathrm{~cm}^{2}$ were polished with a different grade of emery sheet and finally rinsed with acetone and dried in air prior to experiments for the weight loss method and electrochemical studies. 


\section{Weight loss measurements}

Bacillus thuringiensis EN2 was used, which was isolated from the cooling tower material (Narenkumar et al. 2016). The experiment was performed in three different types of systems. In experimental setup, polished coupons of two different sizes of coupons were placed in $500 \mathrm{~mL}$ flask containing $400 \mathrm{~mL}$ of sterile cooling tower water (CTW) and $1 \%$ of $\mathrm{NB}$ as control (system I). The experimental system II consisted of $400 \mathrm{~mL}$ of CTW along with $1 \%$ of $\mathrm{NB}$ inoculated with $1 \mathrm{~mL}$ of $B$. thuringiensis $\left(1.2 \times 10^{4}\right.$ $\mathrm{CFU} / \mathrm{mL})$. Experimental system III contained $20 \mathrm{ppm}$ of cured ginger extract along with $400 \mathrm{~mL} \mathrm{CTW,} 1 \% \mathrm{NB}$, and $1 \mathrm{~mL}$ of $B$. thurigiensis $\left(1.2 \times 10^{4} \mathrm{CFU} / \mathrm{mL}\right)$. Three coupons were exposed in each of these systems and all the experiment systems were setup in triplicate. The cooling tower water was collected from an industry located at Ranipet, Vellore, Tamil Nadu (latitude 12.953671 and longitude 79.313132), and chloride concentration in the tower water was $660 \mathrm{mg} / \mathrm{L}$. All biocorrosive flasks were incubated at $37^{\circ} \mathrm{C}$ for 28 days in stagnant conditions. The metal coupon from each biocorrosion experimental system was removed at regular intervals (7 days) up to end of the incubation period (28 days). After the weight loss experiment, the MS 1010 coupons were removed from each system and pickled with pickling solution $(1 \mathrm{~L} \mathrm{HCl}$ containing $20 \mathrm{~g}$ of antimony trioxide and $50 \mathrm{~g}$ of stannous chloride for $20 \mathrm{~min})^{5}$. Finally, the corrosion rate (CR) was calculated as described by NACE standards at regular interval of 28 days (NACE 2005). During the biocorrosion studies, antibacterial activity of the GIE and the total viable count (TVC) of the bacterial biofilm on each metal surface exposed in system II and III were scrapped at different time intervals.

\section{Surface analysis}

The corrosion product were collected and crushed into a fine powder and used for X-ray diffraction spectroscopy (XRD) and Fourier transform infra-red spectroscopy (FTIR), and surface film was scrapped using sterile spatula and dissolved in methanol. The resultant solution was injected in the GC-MS (Ostovari et al. 2009). The FTIR (Bruker's VERTEX 70 series) equipped with a narrow band of liquid nitrogen-cooled $\mathrm{HgCdTe}$ (MCT) detector was used for collecting the IR spectra data. A computer controlled XRD system (Bruker-8030) among $10^{\circ}$ and $85^{\circ}$ $2 \theta$ with copper Ká radiation at a rating of $35 \mathrm{kV}, 25 \mathrm{~mA}$ was performed (Rajasekar et al. 2007).

\section{Electrochemical studies}

ES measurements were carried out in a $\mathrm{CH}$ Instrument Inc., USA model CHI608E. The immersed mild steel 1010 coupons $\left(1 \mathrm{~cm}^{2}\right)$ at various time points (with and without EN2 and GIE) were used as working electrode after sealing with Teflon. $\mathrm{Ag} / \mathrm{AgCl}$ was used as reference electrode and a platinum wire was used as counter electrode. The open circuit potential (OCP), Nyquist, and Tafel measurements were carried out at time interval of every 7 days of incubation period. Tafel polarization study was performed with a scan rate of $0.01 \mathrm{mV} / \mathrm{s}$ and OCP at $200 \mathrm{mV}$ towards anodically and cathodically. The impedance study was performed at frequency range of $10,000-0.01 \mathrm{kHz}$ and amplitude at $0.01 \mathrm{mV}$ for the AC signal (Narenkumar et al. 2016; Rajasekar and Ting 2010).

\section{Results and discussion}

Results showed that the minimal inhibitory concentration required for GIE to inhibit growth of EN2 was $20 \mathrm{ppm}$. The growth curve of EN2 with and without GIE on MS 1010 metal surface was shown in Fig. 1. The growth curve showed that growth of EN2 was observed as in the range of $10^{9}$, and in the presence of GIE, growth pattern was reduced up to $10^{4}$. Kim and Park (2013) reported and stated that GIE not affected the growth of bacteria; this may be due to the removal of active compounds affecting PA14 bacteria growth by the extraction procedure of GIE. However, the GIE was reported to inhibit biofilm formation with their changes of phenotype characterization. In this study, the aqueous extraction of GIE inhibited the bacterial growth on MS surface. 20 ppm of GIE was recognized as a dosage having significant antibacterial activity (observed as clear zone of inhibition, i.e., $5 \mathrm{~mm}$ ).

Biofilm formation was analyzed using a microtiter plate assay with crystal violet (Fig. 2) (O'Tool et al. 1999). It

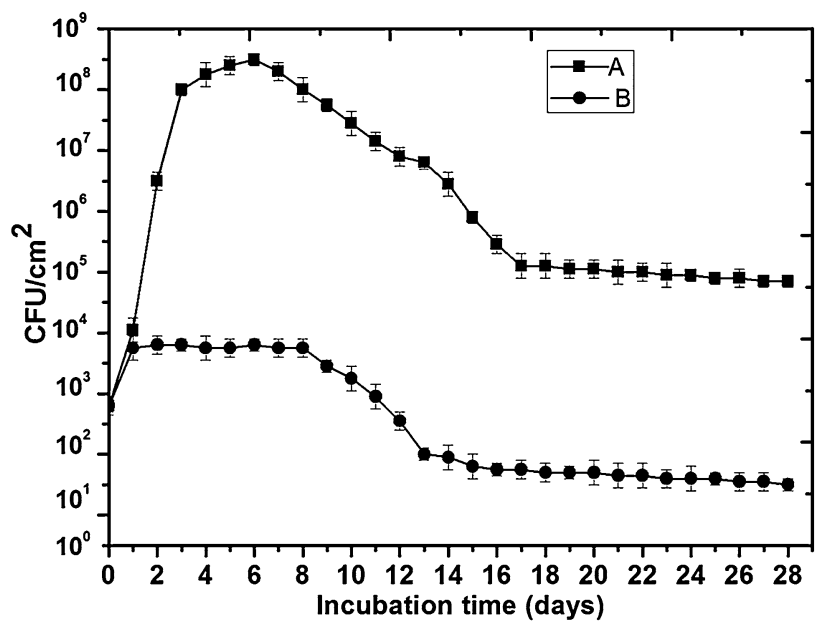

Fig. 1 Growth pattern of Bacillus thuringiensis EN2 on metal surface, a Bacillus thuringiensis EN2, and b Bacillus thuringiensis EN2 treated with ginger extract (GIE) 


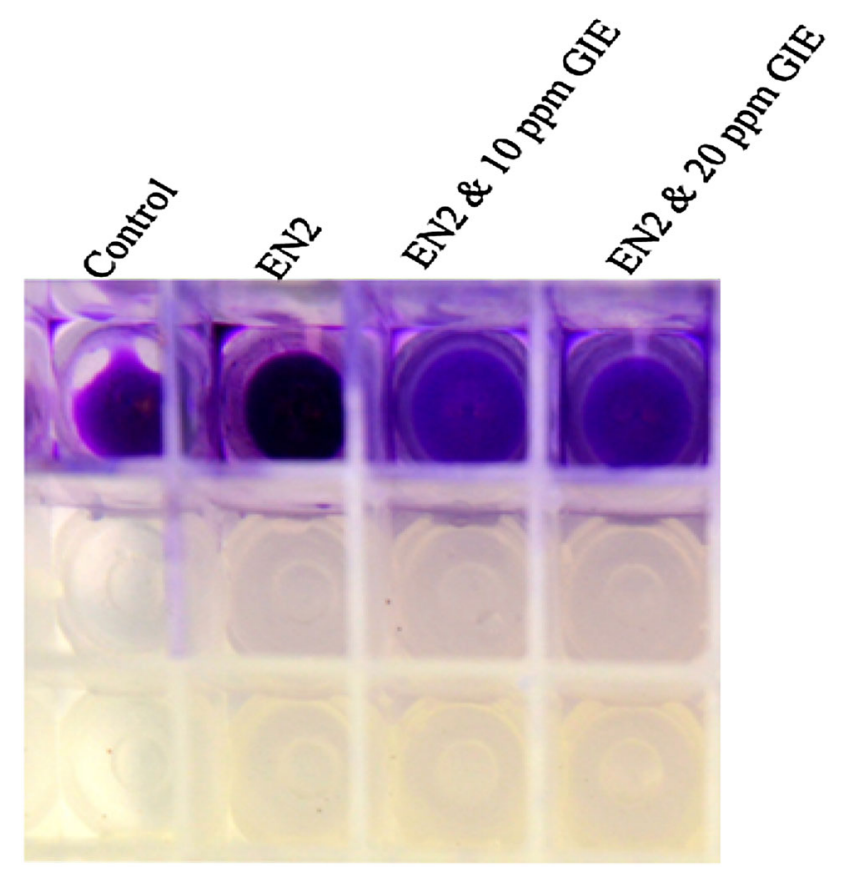

Fig. 2 Static biofilm formation assay for Bacillus thuringiensis EN2 with and without ginger extract

was observed that EN2 was able to forma biofilm on metal surface. However, in the presence of GIE, the biofilm formation was reduced. These results suggest that GIE inhibited biofilm formation of EN2, due to its high antibacterial activity (Kim and Park 2013). In the absence of biocide, the EPS from EN2 biofilm was observed as higher amount of proteins (44\%), carbohydrates (18\%), and lipids $(20 \%)$. In the presence of GIE, a lower amount of proteins $(27 \%)$ and carbohydrates $(9 \%)$ was noted. It can be concluded that GIE inhibits the bacterial metabolism leading to lower production of EPS components. The GIE antibiofilm property may be due to inhibition of regulation gene c-di-GMP levels (Kim and Park 2013).

Colony morphology assay was carried out in Congo red containing agar plate. The pink rugose morphology noticed in agar plate not treated with GIE was due to higher production of exopolysaccharides (Ueda and Wood 2009). On the other hand, we not observed in rugose morphology in GIE-treated agar plates, indicating that the production of exopolysaccharides was strongly reduced (Kim and Park 2013). The motility of EN2 grown with and without GIE was evaluated by agar plate through dendrites. The dendrite length of EN2 cells grown with $20 \mathrm{ppm}$ of GIE was about $38 \pm 1 \mathrm{~mm}$, whereas without GIE was $20 \pm 2 \mathrm{~mm}$. This result reveals that GIE promoting the migration of EN2 on agar plate. The detachment assay on EN2 biofilm formation in plates with and without GIE was shown in Fig. 3. SDS detachment efficiency in the presence of GIE was $77 \%$, whereas without GIE was $42.9 \%$. Hence, GIE film was

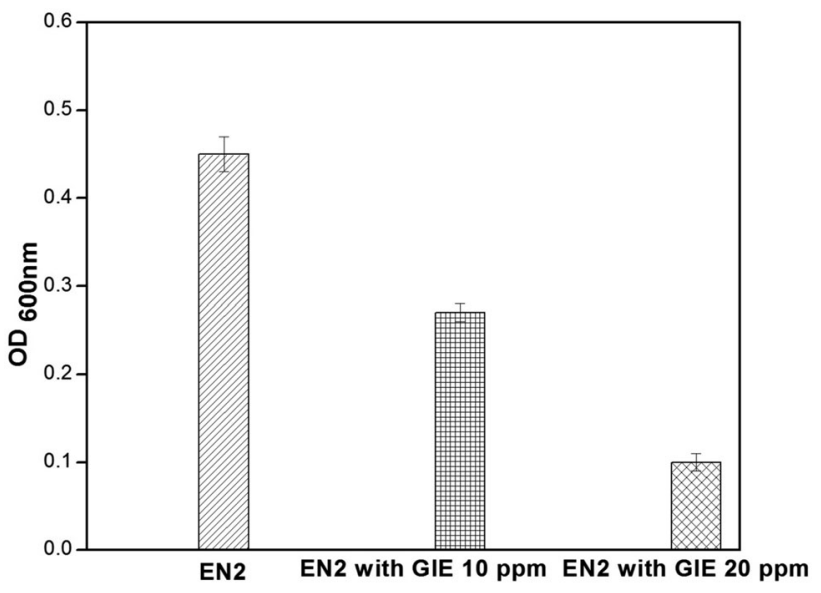

Fig. 3 Biofilm detachment assay for Bacillus thuringiensis EN2 with and without ginger extract

loosely attached on the surface of plate. These assays were clearly explained the effect of GIE in inhibiting EN2 biofilm formation and reducing cellular C-di-GMP concentration, which leads to affect of phenotype characteristics (Kim and Park 2013).

\section{Weight loss experiment}

Weight loss (WL) and corrosion rate (CR) of mild steel 1010 in the three experimental systems (biotic, abiotic, and inhibitor systems) are presented in Table 2. In control system, an average weight loss was noted as $394 \mathrm{mg}$ at the end of the immersion period of 28 days. It was observed that WL of biotic system was around $194 \mathrm{mg}$ at first week and was significantly increased up to $993 \mathrm{mg}$ at the end of fourth weeks, which might be due to the formation of a thick layer of biofilm on the metal surface and alteration of electrochemical parameters on metal surface. Biofilms on any metal surface result in increase corrosion rates (Chongdar et al. 2005; Beech and Sunner 2004; Rajasekar et al. 2008). The microorganisms stimulate the cathodic or anodic reaction and establish the electrolytic environment, which leads to the corrosion of metal surface (Hamilton 1990). Significantly, in the presence of GIE, lower WL and

Table 2 Corrosion data for mild steel 1010 in the presence and absence of bacteria EN2/inhibitor at different immersion period

\begin{tabular}{|c|c|c|c|c|c|c|}
\hline \multirow[t]{2}{*}{ Duration } & \multicolumn{3}{|c|}{ Mean weight loss (mg) } & \multicolumn{3}{|c|}{ Corrosion rate (mm/year) } \\
\hline & Control & Biotic & Biocide & Control & Biotic & Biocide \\
\hline Week 1 & $36 \pm 2$ & $194 \pm 2$ & $18 \pm 2$ & 1 & 5 & 0.4 \\
\hline Week 2 & $175 \pm 2$ & $493 \pm 2$ & $19 \pm 2$ & 2 & 7 & 0.2 \\
\hline Week 3 & $248 \pm 2$ & $711 \pm 2$ & $28 \pm 2$ & 2 & 6 & 0.2 \\
\hline Week 4 & $394 \pm 2$ & $993 \pm 2$ & $41 \pm 2$ & 3 & 7 & 0.2 \\
\hline
\end{tabular}

Corrosion inhibitor efficiency: $80 \%$ 
CR were observed as $41 \mathrm{mg}$ and $0.2 \mathrm{~mm} /$ year, respectively (after 28 days), and CR was highly reduced when compared to biotic and abiotic experimental systems. From these results, it was clear that GIE acted as a biocide inhibiting biofilm formation and thus effectively reducing CR. El-Aziz et al. (2013) reported that GIE reduced the biofilm formation by microbes on metal surface (Al Abbas et al. 2013; Yousfi et al. 2015). The CR of GE system was about $0.2 \mathrm{~mm} / \mathrm{year}$, which was lesser when compared to

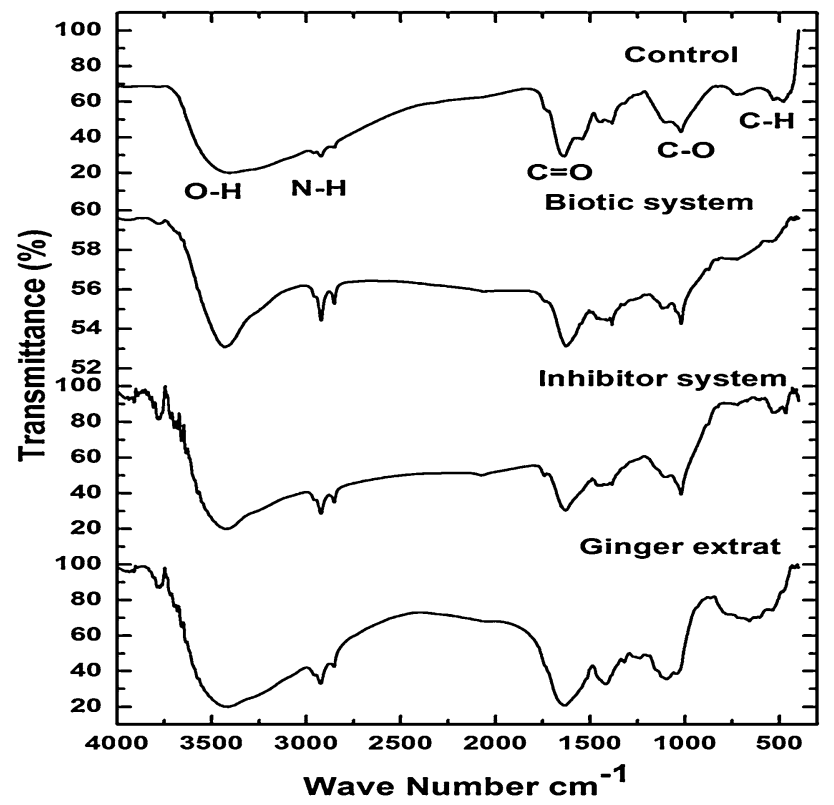

Fig. 4 FTIR spectrum of surface film formed on mild steel 1010 coupons of different biocorrosion systems

Fig. 5 GC-MS spectrum of surface biofilm collected from bacterial EN2 with ginger extract biocorrosion system control ( $3 \mathrm{~mm} /$ year) and biotic system $(7 \mathrm{~mm} /$ year $)$. The corrosion inhibition efficiency was $80 \%$. GIE acted against the bacteria and inhibited the bacterial growth on metal surface. The presence of phytoactive compounds such as gingerol, shogal, and $\beta$-turmerone in ginger extract could be adsorbed on metal surface, which could possibly explain its inhibitory effect on the bacterial growth. Moreover, it could also form a protective layer or coating on metal surface, which prevent biofilm formation (Kim and Park 2013; Al-Fakih et al. 2015; El-Sabbah et al. 2015). Corrosion inhibitors exposed through the metal surface heteroatoms such as oxygen, sulphur, nitrogen, and phosphorus. The inhibitors block the binding sites on metal surface, which leads to a decrease in the corrosion rates (El-Aziz et al. 2013).

\section{Surface analysis}

FTIR spectrum of the surface film of the exposed metal to GIE with EN2 was shown in Fig. 4. In the aqueous extract of GIE, occurance of broad peak at $3300-3400 \mathrm{~cm}^{-1}$ indicated that the presence of $\mathrm{OH}$ group. The peak at 1750 and $1720 \mathrm{~cm}^{-1}$ corresponded to the stretching vibrations of $-\mathrm{C}=\mathrm{O}$ groups of amide (Fig. 4a). In EN2 with GIE system, the peak at 2800 and $1715 \mathrm{~cm}^{-1}$ indicated the presence of $\mathrm{NH}$ group and confirmed the adsorption of amine group on the metal surface. The GIE leads to electron exchange, which was attributed to the formation of productive layer on the metal surface. FTIR revealed that GIE was adsorbed on metal surface, with coordination of iron oxide with the functional group of GIE (gingerol, shogal, and $\beta$-turmerone) leading to the formation of a layer on the metal

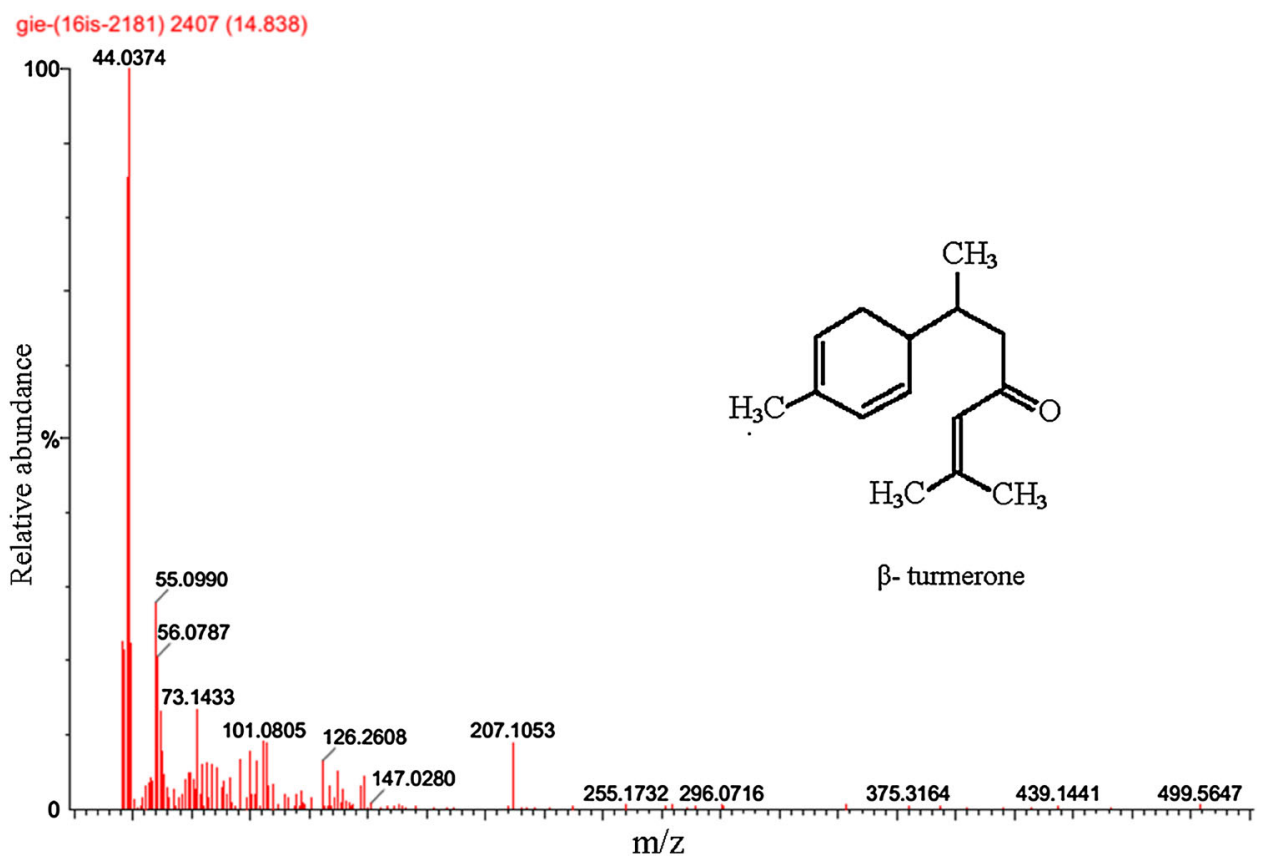


surface. This layer further inhibited the bacterial attachment on MS surface due to antimicrobial activity. GC-MS spectrum of surface film of bacteria with GIE was shown in Fig. 5. In system III, biocide compounds ( $\beta$-turmerone, $\alpha$ turmerone, curlone, and shogal) were observed. It can be confirm that GIE coating the metal surface acted as protective layer and inhibit the biofilm formation as well as corrosion.

Corrosion products formed on the MS surface at the end of the incubation period were characterized by XRD (Fig. 6). Iron hydroxide (FeOOH) and ferrous sulphide $(\mathrm{FeS})$ were detected in the control system (Fig. 6a), while in the biotic system (Fig. 6b), higher intensity of peaks $\mathrm{FeOOH}, \mathrm{FeS}$, iron oxide $\left(\mathrm{Fe}_{2} \mathrm{O}_{3}\right)$, and iron oxychloride $(\mathrm{FeOCl})$ were observed. These results reveal that EN2 had oxidized the iron, sulphide, and chloride, and deposited as corrosion product of iron and sulphide (Beech and Sunner 2004; Rajasekar et al. 2008; Booth 1971). In the presence of GIE, the intensity of peaks was reduced which was due to the inhibition of the bacterial biofilm on the MS metal surface.

\section{Electrochemical impedance studies}

Nyquist plot for the MS coupons of various biocorrosion systems at different duration of incubation period is shown in Fig. 7. The corresponding charge transfer resistance $\left(R_{\mathrm{ct}}\right)$ and solution resistance $\left(R_{\mathrm{s}}\right)$ are presented in a Table 3.

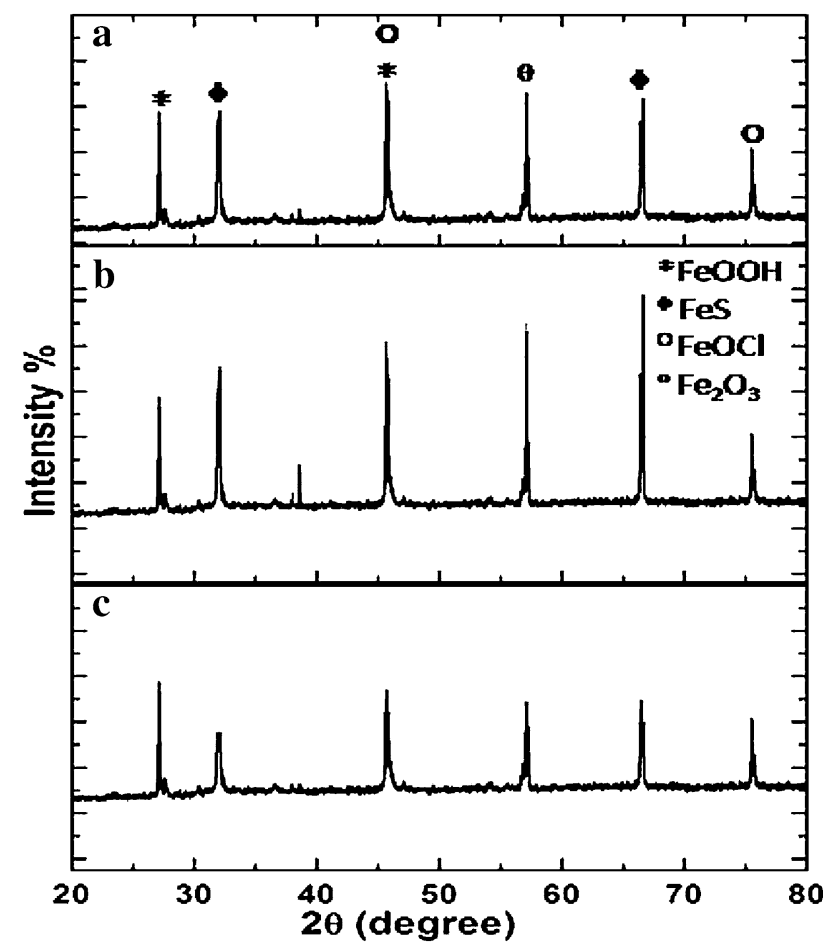

Fig. 6 XRD spectrum of corrosion product of mild steel 1010 after immersion of various biocorrosion systems: a control, b biotic, and c inhibitor (ginger extract)
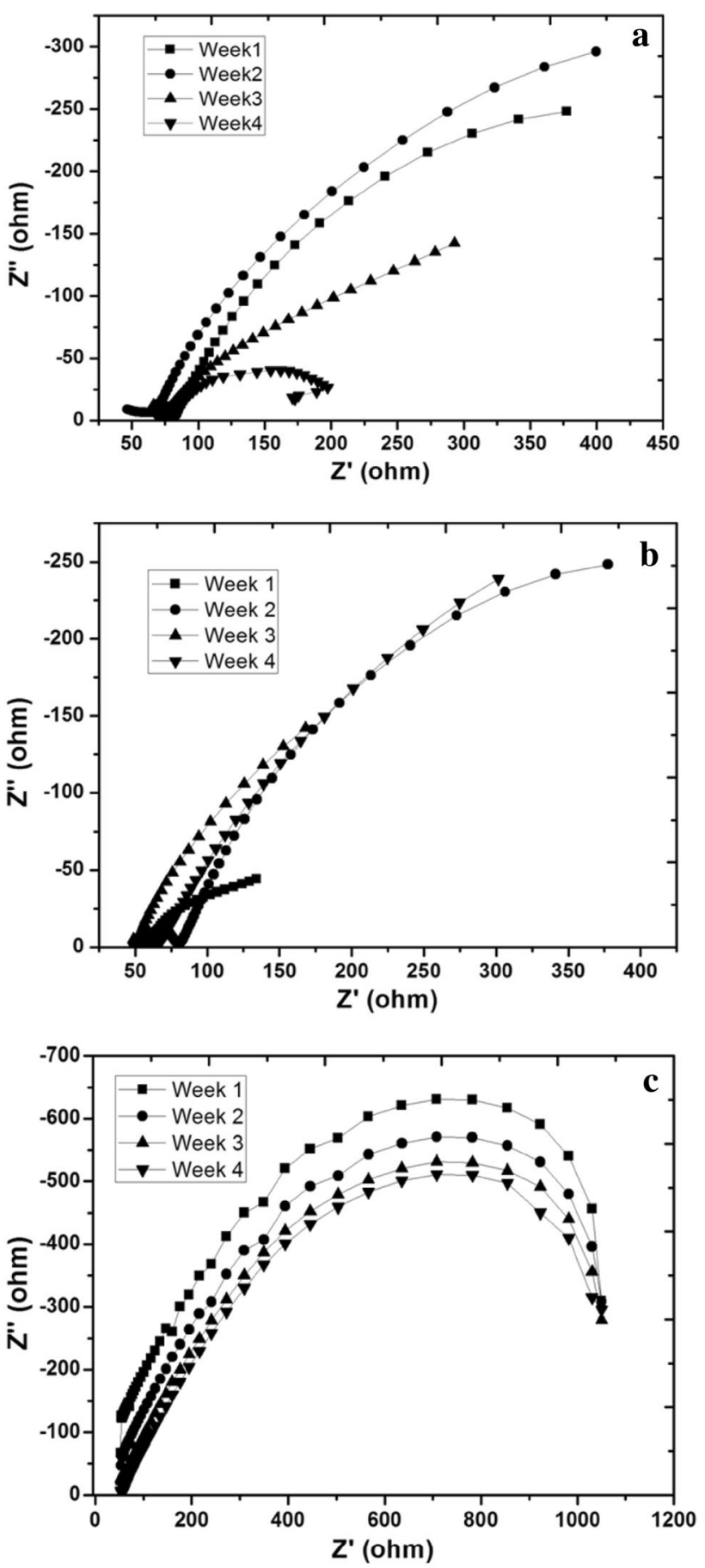

Fig. 7 Nyquist plots of mild steel 1010 coupons collected from various biocorrosion systems at different incubation period: a control, b biotic, and $\mathbf{c}$ inhibitor (ginger extract)

In biocide system (GIE), Nyquist plot exhibited a semicircle; on the other hand, in the biotic system, it was depressed in semicircle (Fig. 7) at high frequency region, due to formation of biofilm on the metal surface (Sabino et al. 2010). Nyquist plot for the control and biotic system (Fig. 7a, b) shows the depressed circle and the lesser $R_{\mathrm{ct}}$ 
Table 3 Electrochemical impedance parameters for mild steel 1010 coupons collected from various biocorrosion systems

\begin{tabular}{|c|c|c|c|c|c|c|}
\hline \multirow[t]{2}{*}{ Duration } & \multicolumn{2}{|l|}{ Control } & \multicolumn{2}{|l|}{ Biotic } & \multicolumn{2}{|c|}{ Biocide } \\
\hline & $R_{\mathrm{s}}(\Omega)$ & $R_{\mathrm{ct}}\left(\Omega \mathrm{cm}^{2}\right)$ & $R_{\mathrm{s}}(\Omega)$ & $R_{\mathrm{ct}}\left(\Omega \mathrm{cm}^{2}\right)$ & $R_{\mathrm{s}}(\Omega)$ & $R_{\mathrm{ct}}\left(\Omega \mathrm{cm}^{2}\right)$ \\
\hline Week 1 & 71.82 & 11.29 & 59.95 & 9.27 & 60.44 & 20.25 \\
\hline Week 2 & 46 & 22.6 & 71.82 & 11.29 & 46 & 22.6 \\
\hline Week 3 & 66.07 & 12.65 & 37.18 & 3.91 & 96.7 & 33.2 \\
\hline Week 4 & 71.8 & 10.04 & 39.14 & 1.64 & 79.14 & 34.16 \\
\hline
\end{tabular}

$R_{\mathrm{s}}$ solution resistance, $R_{\mathrm{ct}}$ charge transfer resistance, $E_{\text {corr }}$ corrosion potential, $I_{\text {corr }}$ corrosion current

$\left(1.64 \Omega \mathrm{cm}^{2}\right)$ and $R_{\mathrm{S}}(39.14 \Omega)$ values when compared to GIE system (Fig. 7c), which indicates the formation of non-protective porous layer on the metal surface (Yuvan et al. 2008; Belmokre et al. 1998).

It can be observed (Table 3 ) that the $R_{\mathrm{ct}}$ for the control system increased at the end of second week $\left(22.6 \Omega \mathrm{cm}^{2}\right)$, and furthermore, it decreased gradually at the end of third and fourth weeks $\left(10.04 \Omega \mathrm{cm}^{2}\right)$, which was due to the reduction/dissolution of metallic ion. In biotic system, $R_{\mathrm{ct}}$ value was lower $\left(1.6 \Omega \mathrm{cm}^{2}\right)$ compared to control system and it can be concluded that EN2 has ability to form thick film on the MS 1010 metal surface that accelerates the corrosion process. In addition of GIE, $R_{\mathrm{ct}}$ value was increased and noted that $34.16 \Omega \mathrm{cm}^{2}$ at the end of the fourth week. The increased $R_{\mathrm{ct}}$ in GIE system might be due to the adsorbed chemical compounds of GIE and thus suppression of cathodic/anodic reaction of metal surface.

\section{Polarization studies}

Figure 8 shows the polarization curve of mild steel 1010 coupons of various biocorrosion systems at different incubation periods. From Fig. 8b, the cathodic peak was shifted to lower potential and cathodic current density was increased $\left(72 \mu \mathrm{A} / \mathrm{cm}^{2}\right)$ in the presence of EN2 on the metal surface (Al abbas et al. 2013). An increased corrosion current $\left(56 \mu \mathrm{A} / \mathrm{cm}^{2}\right)$ might be due to the formation of biofilm and EPS on metal surface by EN2. The secreted EPS biomolecules in the presence of microbes are enhanced the cathodic reduction or accelerate to anodic dissolution as corrosion process ( $\mathrm{Al}$ abbas et al. 2013; Lebrini et al. 2011).

The potentiodynamic polarization data for all biocorrosion system for different incubation periods were presented in Table 4 . The corrosion current $\left(I_{\text {corr }}\right)$ for the control system at the first week was $34 \mu \mathrm{A} / \mathrm{cm}^{2}$, which was significantly increased to $39 \mu \mathrm{A} / \mathrm{cm}^{2}$ at the end of the incubation day. The $I_{\text {corr }}$ for biotic system were about 56, 53, 64 and $72 \mu \mathrm{A} / \mathrm{cm}^{2}$, respectively, at different incubation periods. It can be noticed that the $I_{\text {corr }}\left(72 \mu \mathrm{A} / \mathrm{cm}^{2}\right)$ was higher for the biotic system when compared to control system. The enhanced $I_{\text {corr }}$ in the biotic medium was due to the high oxygen diffusion by the formation of biofilm and growth of bacteria (Zhai et al. 2015; Sabino et al. 2010). Furthermore, noticed that in addition of GIE, the $I_{\text {corr }}$ was very lesser $\left(10 \mu \mathrm{A} / \mathrm{cm}^{2}\right)$ compared to control $\left(39 \mu \mathrm{A} / \mathrm{cm}^{2}\right)$ and biotic system $\left(72 \mu \mathrm{A} / \mathrm{cm}^{2}\right)$. The decreased $I_{\text {corr }}$ was due to the presence of biocide, which absorbed on the metal surface and forms a protective film. The corrosion potential $\left(E_{\text {corr }}\right)$ for the control and experimental system at the end of the incubation period were about $-551,-582$, and $-574 \mathrm{~V}$, respectively. In the presence of GIE, the $E_{\text {corr }}$ values showed that a positive potential shift which was due to the GIE was adsorbed on the metal surface and leads to reduction of corrosion. This phenomena leads to the inhibition of the CR on the mild steel surface and this observation was supported by Yuvan et al. (2008). Table 4 presented the polarization resistance $\left(R_{\mathrm{p}}\right)$ values for immersed MS at various incubation periods. It was clear from Table 4 that the $R_{\mathrm{p}}$ were significantly reduced $(0.9 \mathrm{O})$ in the presence of EN2. Thus, the $R_{\mathrm{p}}$ value of GIE system was higher than that of biotic and control system at the end of the fourth week. Hence, it can be evident from the electrochemical studies that GIE can act as a potential biocide for control of MIC in a cooling water system.

\section{Conclusion}

In the present study, the effect of the green biocide GIE on the corrosion inhibition of MS 1010 was investigated. As a result, $20 \mathrm{ppm}$ of GIE were identified as optimal dosage for inhibition of biofilm on MS surface, leading to corrosion inhibition efficiency of $80 \%$. GIE was biodegradable, nontoxic, easy to handling, and available as rich natural resources. Ginger was widely used for effective biocide in many industries including paper and oilfield factories. FTIR results confirmed that GIE was adsorbed on the metal 

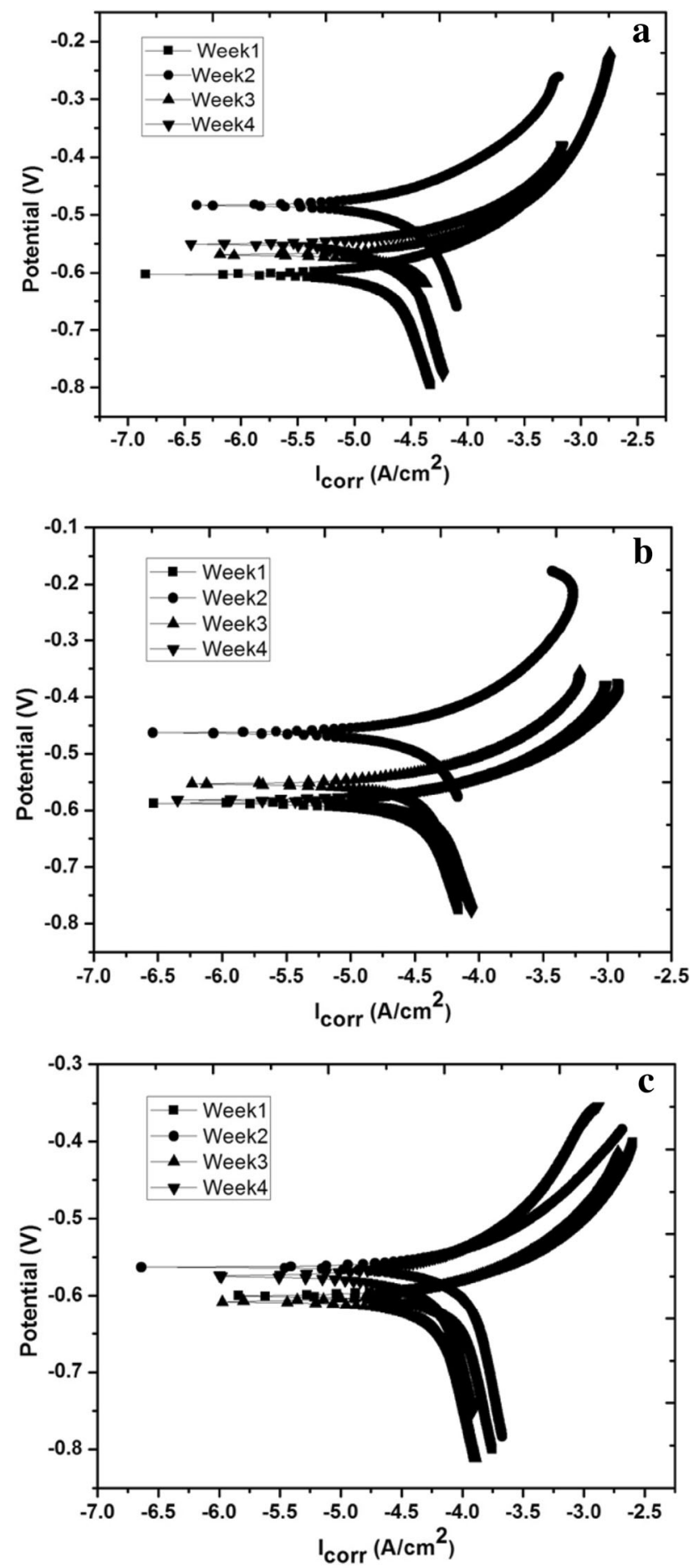

Fig. 8 Polarization plots of mild steel 1010 coupons collected from various biocorrosion systems at different incubation period: a control, b biotic, and $\mathbf{c}$ inhibitor (ginger extract)

surface with the co-ordination with iron oxide, forming an organic productive layer, which inhibits biofilm and controlled MIC. XRD analysis revealed low intensity of corrosion products in the presence of GIE with EN2 than biotic and abiotic system. In this study, WL, ES, and

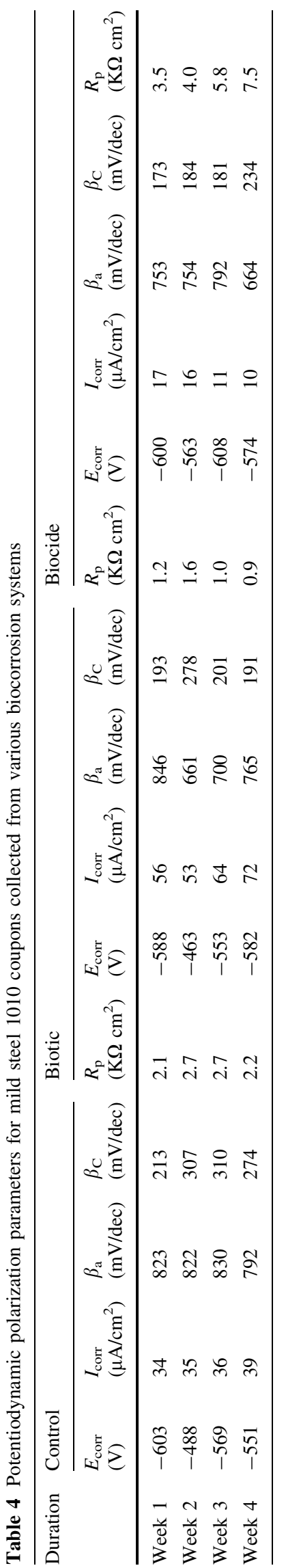


surface analysis (FTIR and XRD) data showed that EN2 bacteria were capable of causing corrosion of MS 1010, which can be effectively inhibited by GIE at the optimum concentration of 20 ppm GIE in cooling water systems.

Acknowledgements A. Rajasekar is thankful to the University Grants Commission (MRP-MAJOR-MICRO-2013-31825), Department of Biotechnology (Government of India) for awarding Ramalingaswami re-entry Fellowship (BT/RLF/Re-entry/17/2012), Department of Science and Technology for awarding Young Scientist Award (SB/YS/LS-40/2013), and Science and Engineering Research Board, Department of Science and Technology, Government of India (EEQ/2016/000449).

\section{Compliance with ethical standards}

Conflict of interest The authors declare that they have no conflict of interest in the publication.

\section{References}

Al Abbas FM, Williamson C, Bhola SM, Spear JR, Olson DL, Mishra B (2013) Microbial corrosion in line pipe steel under the influenced of a sulphate reducing consortium isolated from an oil filed. J Mater Eng Perform 22(11):3517-3529

Al-Fakih AM, Aziz M, Sirat HM (2015) Turmeric and ginger as green inhibitors of mild steel corrosion in acidic medium. J Mater Environ Sci 6(5):1480-1487

Amin MA, Ibrahim MM (2011) Corrosion and corrosion control of mild steel in concentrated $\mathrm{H}_{2} \mathrm{SO}_{4}$ solutions by a newly synthesized glycine derivative. Corros Sci 53:873-885

Ansari KR, Quraishi MA (2015) Experimental and quantum chemical evaluation of Schiff bases of isatin as a new and green corrosion inhibitors for mild steel in $20 \% \mathrm{H}_{2} \mathrm{SO}_{4}$. J Tai Inst Chem Eng $54: 145-154$

Aquaprox (2009) Treatment of cooling water. Springer, Berlin. ISBN:3-642-01984-5, 978-3-642-01985-2

Aribo S, Olusegun SJ, Ibhadiyi LJ, Oyetunji A, Folorunso DO (2016) Green inhibitors for corrosion protection in acidizing oilfield environment. J Ass Arab Uni Basic App Sci. doi:10.1016/j. jaubas.2016.08.001

Banerjee G, Malhotra SN (1992) Contribution to adsorption of aromatic amines on mild steel surface from $\mathrm{HCl}$ solutions by impedance, UV, and Raman spectroscopy. Corrosion 48:10

Beech IB, Sunner J (2004) Biocorrosion: towards understanding interactions between biofilms and metals. Curr Opin Biotechnol $15: 181-186$

Belmokre K, Azzouz N, Kermiche F, Wery M, Pagetti J (1998) Corrosion study of carbon steel protected by a primer, by electrochemical impedance spectroscopy (ES) in $3 \% \mathrm{NaCl}$ medium and in a soil simulating solution. Mater Corros 49:108-113

Betoni JE, Mantovani RP, Barbosa LN, Di Stasi LC (2006) Fernandes junior a synergism between plant extract and antimicrobial drugs used on Staphylococcus aureus diseases. Mem Inst Oswaldo Cruz 101:387-390

Bhawsar J, Jain PK, Jain Preeti (2015) Experimental and computational studies of Nicotiana tabacum leaves extract as green corrosion inhibitor for mild steel in acidic medium. Alexandria Eng J 54:769-775

Bhola SM, Singh G, Mishra B (2013) Flavin mononucleotide as a corrosion inhibitor for hot rolled steel in hydrochloric acid. Int $\mathrm{J}$ Electro Chem Sci 8:5635-5642
Booth GH (ed) (1971) Microbiological corrosion, M and B monographs CE11. Mills and Boon, London

Chongdar S, Gunasekaranamd G, Kumar P (2005) Corrosion inhibition of mild steel by aerobic biofilm. Electrochim Acta 50:4655-4665

Downward BL, Talbot RE, Haak TK (1997) Tetrakis hydroxymethyl phosphonium sulphate (THPS). A new industrial biocide with low environmental toxicity, corrosion $=97$. NACE International, Houston

Dubois M, Gilles KA, Hamilton JK, Rebers PT, Smith F (1956) Colorimetric method for determination of sugars and related substances. JF Anal Chem 28:350-356

El-Aziz A, Fouda S, Ahmed Abdel N, Ibrahim M, Fakih M (2013) Ginger extract as green corrosion inhibitor for steel in sulfide polluted salt water. J Korean Chem Soc 57(2):272-278

El-Sabbah MMB, Khalil HFY, Mahross MH, Mahran BNA, Gomaa AZ (2015) Aqueous extract of ginger as green corrosion inhibitor for mild steel in hydrochloric acid solution. Int J Sci Eng Res 6(6): 1502-1508

El-Sayed A (1997) Phenothiazine as inhibitor of the corrosion of cadmium in acidic solutions. J Appl Electrochem 27:193

El-Shamy AM, Soror TY, El-Dahan HA, Ghazy EA, Eweas AF (2009) Microbial corrosion inhibition of mild steel in salty water environment. M Chem Phys 114:156-159

Greenberger JS, Donahue D, Sakakeeny M (1979) Induction of ecotropic endogenous murine leukemia virus in long-term bone marrow cultures from mouse strains of varying natural leukemia incidence. J Reticuloendothel Soc 26:839-853

Guiamet PS, Gomez de Saravia SG (2005) Laboratory studies of biocorrosion control using traditional and environmentally friendly biocides: an overview. Latin Am Appl Res 35(4):295-300

Hamilton WA (1990) Sulphate-reducing bacteria and their role in biocorrosion. International workshop on industrial biofouling and biocorrosion. Springer, Stuttgart

Javaherdashti R (2008) Microbiologically influenced corrosion-an engineering insight. Springer, London

Kamal C, Sethuraman MG (2012) Caulerpin A bis-indole alkaloid as a green inhibitor for the corrosion of mild steel in $1 \mathrm{M} \mathrm{HCl}$ solution from the marine alga Caulerpa racemosa. Ind Eng Chem Res 51:10399-10407

Kamal C, Sethuraman MG (2013) Kappaphycus alvarezii-a marine red alga as a green inhibitor for acid corrosion of mild steel. Mate Corros 64:9999

Kim HS, Park HD (2013) Ginger extract inhibits biofilm formation by Pseudomonas aeruginosa PA14. PLoS ONE 8:9

Krishna A, Banerjee A (1999) Antimicrobial screening of some Indian spices. Phyt other Res 13:616-618

Lalpuria M, Karwa V, Anantheswaran RC, Floros JD (2012) Modified agar diffusion bioassay for better quantification of Nisaplin ${ }^{\circledR}$. J Appl Microbiol 114:663-671

Lebrini M, Traisnel M, Gengembre L, Fontaine G, Lerasle O, Genet N (2011) Electrochemical impedance spectroscopy and X-ray photoelectron spectroscopy study of the corrosion behaviour of galvanized steel and electroplating steel. A Sur Sci 257:3383-3387

Lewis K (2001) Riddle of biofilm resistance. Antimicrob Agents Chemother 45:999-1007

Little BJ, Lee JS (2007) Microbiologically influenced corrosion. Wiley, Hoboken

Liu Y, Yang CH, Li J (2007) Influence of extracellular polymeric substances on Pseudomonas aeruginosa transport and deposition profiles in porous media. Environ Sci Technol 41:198

Lutey RW (2001) A review and comparison of MIC indices (Models). 62nd International Water Conference. Paper 4, October 21-25, Pittsburgh, PA, USA 
Malhotra S, Singh G (2005) Vitamins-potential inhibitors for nickel in acidic media. Surf Eng 21(3):187-192

NACE International (2005) Preparation, installation, analysis and interpretation of corrosion coupons in oilfield operations. NACE International

Narenkumar J, Madhavan J, Nicoletti M, Benelli G, Murugan K, Rajasekar A (2016) Role of bacterial plasmid on biofilm formation and its influence on corrosion of engineering materials. J Bio Tribo Corros. doi:10.1007/s40735-016-0054-z

Nathiya RS, Raj V (2016) Evaluation of Dryopteris cochleata leaf extracts as green inhibitor for corrosion of aluminium in $1 \mathrm{M}$ $\mathrm{H}_{2} \mathrm{SO}_{4}$. Egypt J Petrol. doi:10.1016/j.ejpe.2016.05.002

Natta L, Orapin K, Krittika N, Pantip B (2008) Essential oil from five Zingiberaceae for anti food-borne bacteria. Int Food Res J 15:337-346

O'Hara CM, Steward CD, Wright JL, Tenover FC, Miller JM (1998) Isolation of Entero bacter intermedium from the gallbladder of a patient with cholecystitis. J Clin Microbiol 36:3055-3056

O'Tool GA, Pratt LA, Watnicr PI, Newman DK, Weaver VB, Kolter R (1999) Genetic approaches to study of biofilm. Methods in enzymology, vol 310. Plenum Press, New York, pp 91-109

Odewunmi NA, Umoren SA, Gasem ZM, Ganiyu SA, Muhammad Q (2015) 1-citrulline: an active corrosion inhibitor component of watermelon rind extract for mild steel in $\mathrm{HCl}$ medium. J Tai Inst Chem Eng 51:1-9

Ostovari A, Hoseinieh SM, Peikari M, Shadizadeh SR, Hashemi SJ (2009) Corrosion inhibition of mild steel in $1 \mathrm{M} \mathrm{HCl}$ solution by henna extract: a comparative study of the inhibition by henna and its constituents (Lawsone, gallic acid, a-D-glucose and tannic acid). Corros Sci 51:1935-1949

Padmavathi AR, Periyasamy M, Pandian SK (2015) Assessment of 2, 4-di-tert-butylphenol induced modifications in extracellular polymeric substances of Serratia marcescens. Bioresour Technol 188:185-189

Park M, Bae J, Lee DS (2008) Antibacterial activity of [10]-gingerol and [12]-gingerol isolated from ginger rhizome against periodontal bacteria. Phytother Res 22:1446-1449

Radojcic I, Berkovic K, Kovac S, Vorkapic-Furac J (2008) Natural honey and black radish juice as tin corrosion inhibitors. J Corros Sci 50:1498-1504

Raja PB, Sethuraman MG (2008) Inhibitive effect of black pepper extract on the sulphuric acid corrosion of mild steel. Mat Lett 62:2977-2979

Raja PB, Sethuraman MG (2009) Inhibition of corrosion of mild steel in sulphuric acid medium by Calotropis procera. Pigment Resin Technol 38(1):33-37

Raja PB, Sethuraman MG (2010) Studies on the inhibition of mild steel corrosion by Rauvolfia serpentina in acid media. JMEPEG. 19:761-766

Rajasekar A, Ting YP (2010) Microbial corrosion of aluminum 2024 aeronautical alloy by hydrocarbon degrading bacteria Bacillus cereus ACE4 and Serratia marcescens ACE2. Ind Eng Chem Res 49:6054-6061

Rajasekar A, Ting YP (2011) Role of inorganic and organic medium in the corrosion behavior of Bacillus megaterium and Pseudomonas sp. in stainless steel SS 304. Ind Eng Chem Res 50:12534-12541

Rajasekar A, Ganesh Babu T, Maruthamuthu S, Pandian SK, Mohanan S, Palaniswamy N (2007) Biodegradation and corrosion behaviour of Serratia marcescens ACE2 isolated from an Indian diesel-transporting pipeline. World J Microbiol Biotechnol 23:1065-1074

Rajasekar A, Maruthamuthu S, Ting Y (2008) Electrochemical behavior of Serratia marcescens ACE2 on carbon steel API 5LX60 in organic/aqueous phase. Ind Eng Chem Res 47:7525-7532

Sabino R, Azambuja DS, Goncalves RS (2010) Electrochemical behaviour aluminium alloy AA2024 in aqueous solutions in the presence of caffeine. J Solid State Electrochem 14:1255-1260

Sebiomo A, Awofodu AD, Awosanya AO, Awotona FE, Ajayi AJ (2011) Comparative studies of antibacterial effect of some antibiotics and ginger (Zingiber officinale) on two pathogenic bacteria. J Microbiol Antimicrob 3:18-22

Shaily BM, Alabbas FM, Bhola R, Spear JR, Mishra B, Olson DL, Kakpovbia AE (2014) Neem extract as an inhibitor for biocorrosion influenced by sulfate reducing bacteria: a preliminary investigation. Eng Fail Anal 36:92-103

Singh A, Quraishi MA (2013) The extract of Jamun (Syzygium cumini) seed as green corrosion inhibitor for acid media. Res Chem Intermed. doi:10.1007/s11164-013-1398-3

Swaroop BS, Noyel Victoria S, Manivannan R (2016) Azadirachta indica leaves extract as inhibitor for microbial corrosion of copper by Arthrobacter sulfureus in neutral $\mathrm{pH}$ conditions-a remedy to blue green water problem. J Tai Inst Chem Eng 000:1-10

Ueda A, Wood TK (2009) Connecting quorum sensing, c-di-GMP, pel polysaccharide, and biofilm formation in Pseudomonas aeruginosa through tyrosine phosphatase TpbA (PA3885). PLoS Pathog 5:1-15

Yousfi F, El Azzouzi M, Ramdani M, Elmsellem H, Aouniti A, Saidi N, Mahi BE, Chetouani A, Hammouti B (2015) Zingiber officinal roscoe extract using as green corrosion inhibitor for mild steel in $1 \mathrm{M} \mathrm{HCl}$ media. Der Pharma Chemica 7(7):377-388

Yuvan SJ, Xu FJ, Pehkonen SO, Ting YP, Kang ET, Neoh KG (2008) Biocorrosion behaviour of titanium oxide/butoxide-coated stainless steel. J Electrochem Soc 155:196-210

Zhai X, Ma X, Myamina M, Duan J, Hou B (2015) Electrochemical study on 4,5-dichloro-2-n-octyl-4-isothiazolin-3-one-added zinc coated in phosphate buffer saline medium with Escherichia coil. J Solid State Electrochem 19(8):2213-2222 